\title{
STUDI BAHAN TAMBAH SERAT ECENG GONDOK PADA LASTON TIPE XI TERHADAP INDEKS MARSHALL TEST MENGGUNAKAN KERIKIL MANTUP
}

\author{
Sugeng Dwi Hartantyo ${ }^{1}$; Rasiyo Hepiyanto ${ }^{2}$ \\ ${ }^{1,2}$ Fakultas Teknik Unisla Lamongan
}

\begin{abstract}
Laston is a mixture of coarse aggregate, fine aggregate, and filler with a binder under the temperature of 145-155oC with the composition being studied and regulated by technical specifications. Laston itself is commonly used in Indonesia with continuous gradations used for heavy traffic loads. Water hyacinth is a water weed that once grow and develop, it has high cellulose fiber content, which is about 60\%.For that, done a research to add a hot asphalt mixture material that aims to improve the quality of mixed result. The selected material is natural water hyacinth. The method used is trial and error with reference of SNI 03-1737-1989. Variations used are 3\%, 5\%, and 7\% of the asphalt weight, asphalt level used Is $5.61 \%$.The result of this study is Marshall evaluation where the greatest score obtained for stability is $1325 \mathrm{~kg}$, Flow is $3.73 \mathrm{~mm}$, Quotient Marshall is $401.02 \mathrm{~kg} / \mathrm{mm}$, VMA is $66.30 \%$, VFWA is $19.25 \%$, and VIM score is $54.35 \%$. With this result, the asphalt mixture can not be used because the results of VMA, VFWA, and VIM have not been suitable on specification of SNI 03-1737-1989.
\end{abstract}

Keywords: Laston, Asphalt Concrete, Water Hyacinth, SNI 03-1737-1989.

\begin{abstract}
Abstrak
Laston adalah campuran agregat kasar, agregat halus, dan pengisi dengan pengikat di bawah suhu 145 $1550 \mathrm{C}$ dengan komposisi sedang dipelajari dan diatur oleh spesifikasi teknis. Laston sendiri biasa digunakan di Indonesia dengan gradasi kontinu yang digunakan untuk beban lalu lintas yang berat. Eceng gondok adalah gulma air yang setelah tumbuh dan berkembang, ia memiliki kandungan serat selulosa yang tinggi, yaitu sekitar 60\%. Untuk itu, dilakukan penelitian untuk menambahkan bahan campuran aspal panas yang bertujuan untuk meningkatkan kualitas hasil campuran. Bahan yang dipilih adalah eceng gondok air alami. Metode yang digunakan adalah coba-coba dengan mengacu pada SNI 03-1737-1989. Variasi yang digunakan adalah 3\%, 5\%, dan 7\% dari berat aspal, tingkat aspal yang digunakan adalah 5,61\%. Hasil penelitian ini adalah evaluasi Marshall dimana skor terbesar yang diperoleh untuk stabilitas adalah $1325 \mathrm{~kg}$, Aliran adalah 3,73 mm, Quotient Marshall adalah 401,02 kg / mm, VMA adalah 66,30\%, VFWA adalah 19,25\%, dan skor VIM adalah 54,35\%. Dengan hasil ini, campuran aspal tidak dapat digunakan karena hasil VMA, VFWA, dan VIM belum sesuai dengan spesifikasi SNI 03-1737-1989.
\end{abstract}

Kata Kunci: Laston, Aspal Beton, Eceng gondok, SNI 03-1737-1989.

\section{PENDAHULUAN}

Jalan adalah sebagai salah satu prasarana transportasi sangat penting pada kemajuan pembangunan kehidupan masyarakan dalam memajukan kehidupan masyarakat. Struktur perkerasan jalan mempunyai peran penting dalam memberikan pelayanan yang optimal agar masyarakat dapat menikmati jalan dengan nyaman dan cepat sampai tujuan agar dapat tercipta pemerataan pembangunan. Perkerasan jalan merupakan lapisan perkerasan yang terletak 
diantara lapisan tanah dasar dan roda kendaraan yag berfungsi memberikan pelayanan kepada sarana transportasi, kemudian diharapkan agar waktu yang telah ditentukan tidak terjadi kerusakan yang berart (www.ilmutekniksipil.com).Diakse tgl 27April.Salah satu jenis perkerasan aspal pada spesifikasi ini adalah lapis beton aspal (Laston) atau lebih dikenal dengan AC (AsphaltConcrete). Laston lebih tahan terhadap pelelehan plastis akan tetapi cukup peka terhadap retak. Tipe kerusakan umum yang dialami campuran laston adalah retak dan atau pelepasan butir. Dari hasil penelitian disimpulkan bahwa campuran ini perlu perbaikan dalam hal kelenturan dan keawetannya (Yamin, 2002). Bahan tambah additive sebagai campuran aspal yang di gunakan biasanya serat selulosa contohnya road cell 50. Untuk mendapatkan bahan adiktif tersebut tidak mudah dan bahan tersebut mahal. Oleh karena itu perlu dicari alternatif pengganti serat selulosa tersebut. Eceng gondok merupakan suatu gulma air yang sekali tumbuh dan berkembang ternyata mempunyai kandungan serat selulosa cukup tinggi, yakni berkisar $60 \%$. Hal ini sangat memungkinkan bahwa eceng gondok berpotensi sebagai bahan dasar pembuatan selulosa yang kedepannya dapat diaplikasikan ke arah yang beragam. Maka dari itu penelitian ini akan menggunakan eceng gondok sebagai bahan adiktif karena merupakan serat alami yang mudah di temukan dan murah (Kumalawati, 2013). Beban lalu lintas yang melewati batas syarat batas sering terjadi sehingga perlu adanya pertimbangan khusus dalam melakukan perencanaan campuran aspal termasuk meningkatkan mutu aspal. Pemikiran untuk memodifikasi bahan aspal dengan additive yang diharapkan dapat memperbesar energi perlekatan aspal terhadap batuan. Zat additive biasanya dapat mengurangi kerusakan pengelupasan akibat terbakar oleh sinar matahari salah satunya adalah menggunakan serat eceng gondok. Maka motifasi saya untuk melakukan penelitian ini adalah untuk memanfaatkan serat eceng gondok sebagai bahan tambahan campuran Laston. Mengingat harga bahan tambahan ini cukup mahal dipasaran maka peneliti ingin menciptakan sebuah terobosan baru untuk membuat serat selulosa dengan menggunakan serat eceng gondok. Tujuan dari penelitian ini antara lain untuk mengetahui proses pembuatan benda uji Laston tipe XI SNI 03 - 1737 - 1989 dengan menggunakan kerikil Mantup dan tambahan (Additive) serat eceng gondok dan untuk mengetahui proses pengujian pembuatan Laston tipe XI SNI 03 - 1737 - 1989 terhadap Indeks Marshall Test dengan menggunakan kerikil Mantup dan tambahan (Additive) serat eceng gondok.

\section{METODE PENELITIAN}

\subsection{Rancangan Penelitian}

Rancangan penelitian adalah proses pengumpulan dan analisis data penelitian. Dalam penelitian ini meliputi perencanaan dan melakukan penelitian. Untuk rancangan perencanaan diawali 
dengan observasi dan evaluasi penelitian yang telah dilakukan dan telah dikenal, sampai pembentukan kerangka diperlukan bukti lebih lanjut. Pada pembahasan Karya ilmiah ini penelitian awal menggunakan metode penelitian laboratorium dengan cara coba-coba /trial and error. Tujuan dari penelitian ini sendiri yaitu untuk mendapatkan hasil dari uji coba pencampuran bahan organik atau gulma berupa eceng gondok. Dimana bahan eceng gondok tersebut nantinya akan di campur dengan campuran aspal panas. Standar yang digunakan dalam penelitian ini telah diakui dan dipakai di Indonesia.

\subsection{Lokasi Penelitian dan Waktu Penelitian}

Waktu penelitian ini dilakukan mulai Bulan April 2018 sampai selesai, bertempat di Laboratorium Fakultas Teknik Sipil, Universitas Islam Lamongan. Jl. Veteran No.53 A Lamongan. Selanjutnya akan dilakukan proses penyusunan laporan dari kegiatan eksperimen tersebut yang nantinya hasil tersebut akan digunakan sebagai bahan pengetahuan bagi mahasiswa dan juga Universitas.

\subsection{Teknik Pengumpulan Data}

Untuk memperoleh data - data yang diperlukan dalam penelitian, maka dilakukan experimen / percobaan di Laboratorium. Disamping itu dilakukan pula beberapa wawancara dengan pihak terkait yang berkepentingan. Adapun teknik pengumpulan data yang digunakan penulis adalah sebagai berikut:

1. Data primer

Data primer merupakan data penelitian yang diperoleh secara langsung dari sumber aslinya baik secara wawancara, jajak pendapat dari individu atau kelompok, maupun hasil observasi dari suatu obyek, kejadian, atau hasil pengujian.

\section{Data sekunder}

Data sekunder merupakan data penelitian yang diperoleh secara tidak langsung, misalnya melalui buku, catatan, bukti yang telah ada, atau arsip, baik yang dipublikasikan maupun yang tidak dipublikasikan secara umum. Dalam hal ini peneliti mengumpulkan data dengan cara berkunjung ke perpustakaan, pusat kajian, pusat arsip atau membaca banyak buku yang berhubungan dengan penelitian.

\subsection{Analisis Data}

Setelah dilakukan penelitian penambahan serat enceng gondok pada campuran aspal panas, peneliti dapat membandingkan hasil dari test Marshall Properties dengan menggunakan dua jenis benda uji dimana dua benda uji tersebut sebelum diberikan tambahan dan sesudah diberikan tambahan serat enceng gondok. Setelah dilakukan pengujian akan mendapatkan hasil, yang selanjutnya dilakukan dengan membuat pemodelan matematika dengan bantuan software MS Excell 2007 untuk mengetahui hubungan antara kadar penambahan. serat selulosa 
dengan kualitas aspal dan nilai- nilai marshall properties. Hasil akhir merupakan model matematika hubungan pengaruh antara penambahan serat enceng gondok terhadap kualitas aspal (penetrasi, titik lembek, titik nyala dan titik bakar aspal serta kehilangan berat aspal) dan, nilainilai marshall properties. Hasil analisis data digunakan sebagai dasar untuk menarik kesimpulan penelitian.

\section{HASIL DAN PEMBAHASAN}

\subsection{Proses Pembuatan Job Mix Formula}

Dalam perencanaan Job Mix Formula proporsi campuran agregat Laston Tipe XI SNI 03-17371989 diperoleh dengan menggunakan metode Trial and Error dengan prosedur kerjanya sebagai berikut, pertama dengan memahami batasan gradasi yang disyaratkan dan selanjutnya memasukkan data spesifikasi yang disyaratkan. Setelah diperoleh komposisi campuran kerja dengan menggunakan metode Trial and error, kemudian dilakukan penimbangan sesuai dengan proporsi campuran Laston Tipe XI SNI 03-1737- 1989 :

\subsection{Hasil Pengujian Marshall Test}

Pengujian Marshall Test dilakukan bertahap sesuai dengan tujuan penelitian, yakni pertama dilakukan untuk mengetahui kadar aspal yang digunakan apakah sudah memenuhi syarat dan kedua untuk mengetahui pengaruh penambahan serat selulosa dalam campuran terhadap nilainilai Marshall Properties yaitu stabilitas Marshall (Marshall Stability), persentase Rongga Terisi Aspal (Void Filed With Asphalt / VFWA), Rongga Dalam Campuran (Void In The Mix / VIM), Rongga dalam agregat (Void In Mineral Aggregate), Kelelahan Plastis (Flow), dan Marshall Quotient (MQ). Untuk hasil marshall test dengan penambahan serat selulosa dapat dilhat pada tabel 1 .

Tabel 1: Hasil Marshall Test dengan Penambahan Serat Eceng Gondok 


\begin{tabular}{|c|c|c|c|c|c|c|}
\hline \%Serat & $\begin{array}{c}\text { Stabilitas } \\
\text { (a) }\end{array}$ & $\begin{array}{c}\text { VFWA } \\
\text { (y) }\end{array}$ & $\begin{array}{l}\mathrm{VMA} \\
\mathrm{B}\end{array}$ & $\begin{array}{l}\text { VIM } \\
0.51\end{array}$ & $\begin{array}{l}\text { Flow } \\
(\mathrm{ma})\end{array}$ & $\begin{array}{c}X 0 \\
\operatorname{man}\end{array}$ \\
\hline$\overline{0}$ & 977 & 19,46 & 64,89 & 51,50 & 3,80 & 248,94 \\
\hline 1 & 66 & 19,25 & 65,17 & 52,29 & 3,73 & 238,72 \\
\hline 3 & 1.091 & 18,30 & 66,27 & 54,06 & 3,33 & 327,31 \\
\hline  & 1.326 & 18.88 & $60 ; 0$ & 34.35 & 3,30 & 401.02 \\
\hline Spesifikasi & I 3 in 30 & \in 65 & لyin 15 & 3.5 &. .4 & $200 \cdot 330$ \\
\hline
\end{tabular}

Sumber : Hasil Perhitungan

Stabilitas (Stability)

Stabilitas adalah kemampuan maksimal suatu benda uji campuran beton aspal menahan beban sampai terjadi kelelehan plastis. Nilai stabilitas akan bertambah dengan naiknya kadar aspal sampai ke batas optimum dan akan mengalami penurunan setelah batas optimum.

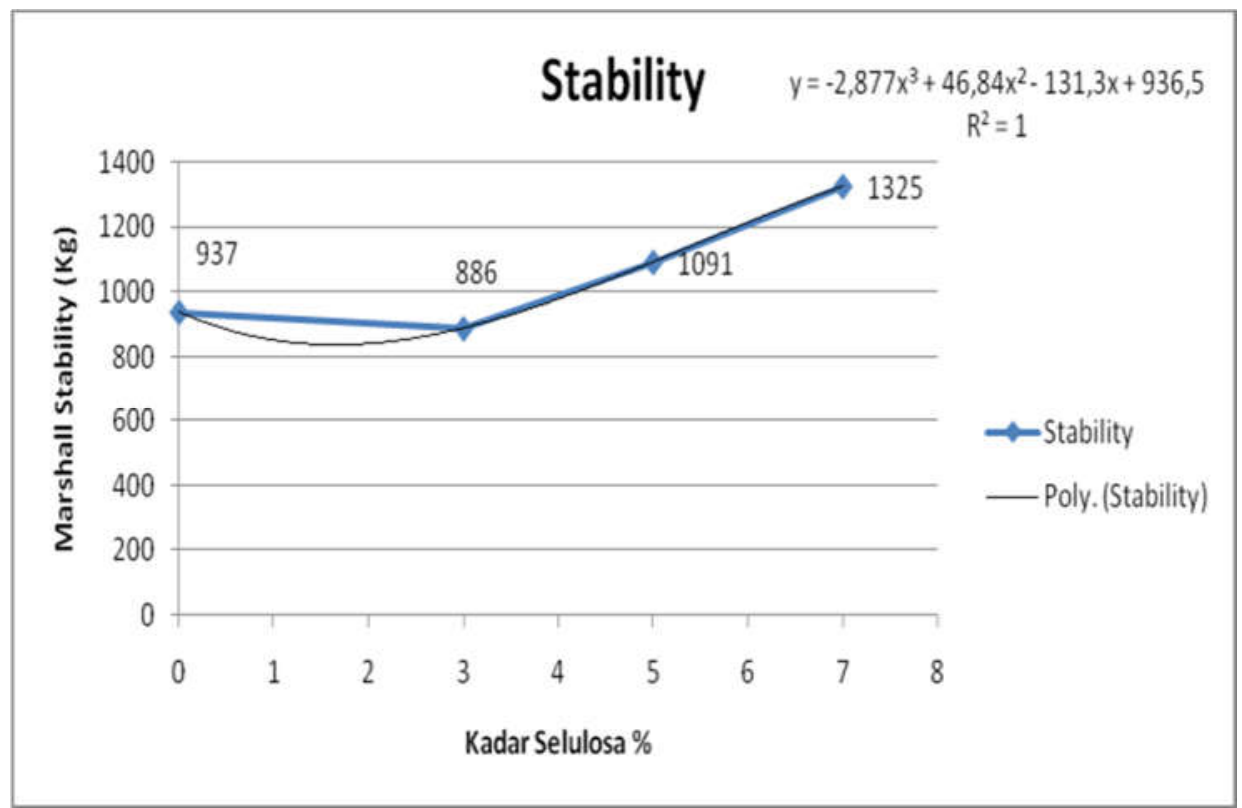

Gambar 1: Grafik Hubungan Stability Marshal dengan Kadar Serat Selulosa 
Sumber : Hasil Penelitian,2018

Rongga Dalam Campuran (Void In The Mix)

Rongga udara dalam campuran (VIM) dalam campuran perkerasan beraspal terdiri atas ruang udara diantara partikel agregat yang terselimuti aspal.

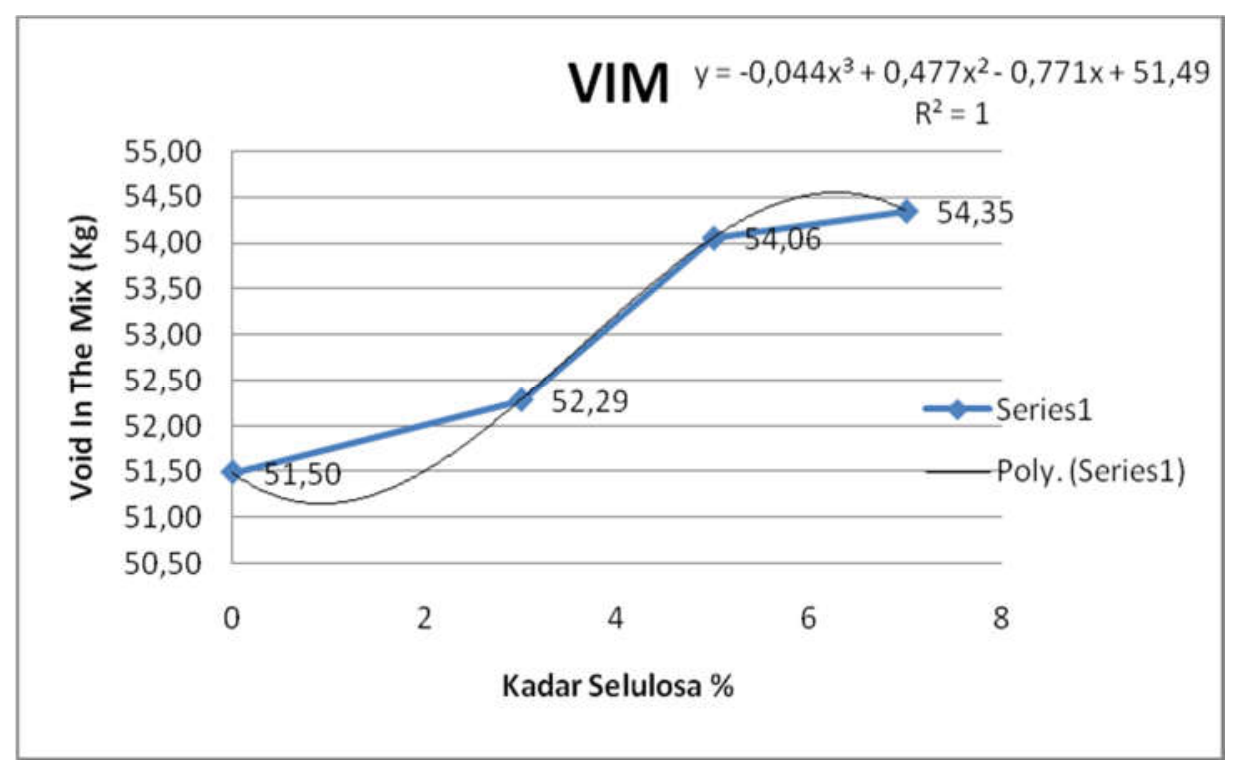

Gambar 2: Grafik Hubungan Void In The Mix dengan Kadar Serat Selulosa Sumber : Hasil Penelitian,2018

Rongga Dalam Mineral (Void In Mineral Aggregate)

Rongga antar mineral agregat (VMA) adalah ruang rongga diantara partikel agregat pada suatu perkerasan, termasuk rongga udara dan volume aspal efektif (tidak termasuk volume aspal yang diserap agregat).

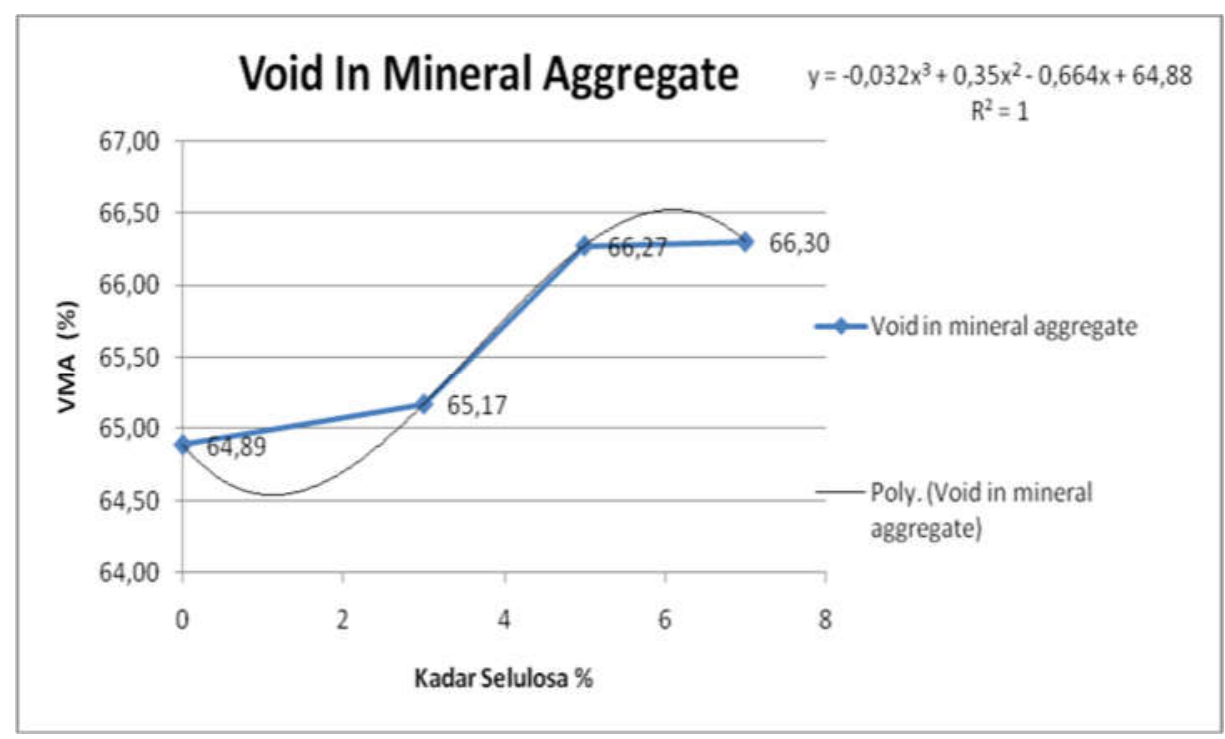

Gambar 3: Grafik Hubungan Void In Mineral Agregate dengan Kadar Serat Selulosa Sumber :

Hasil Penelitian,2018 


\section{Rongga Terisi Campuran Beraspal (Void Filled With Asphalt)}

Rongga terisi aspal atau Void Filled with Asphalt (VFWA) adalah persen rongga yang terdapat diantara partikel agregat (VMA) yang terisi oleh aspal, tidak termasuk aspal yang diserap oleh agregat.

\section{Rongga Terisi Campuran Beraspal (Void Filled With Asphalt)}

Rongga terisi aspal atau Void Filled with Asphalt (VFWA) adalah persen rongga yang terdapat diantara partikel agregat (VMA) yang terisi oleh aspal, tidak termasuk aspal yang diserap oleh agregat.

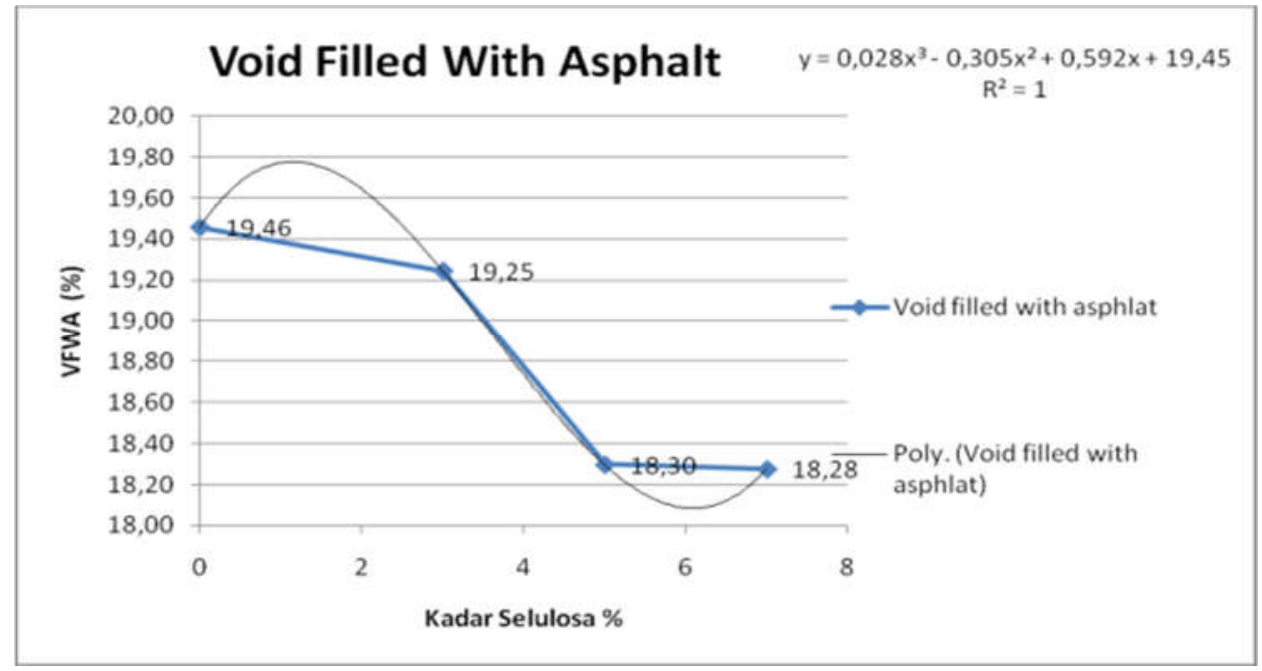

Gambar 4: Grafik Hubungan Void Filled With Asphalt dengan Kadar Serat Selulosa Sumber : Hasil Penelitian,2018

\section{Kelelehan (Flow)}

Flow adalah besarnya perubahan (deformasi benda uji) campuran dengan angka kelelehan tinggi serta stabilitas rendah di atas batas maksimum akan cenderung plastis. Campuran dengan angka kelelehan rendah dan stabilitas tinggi dibawah optimum akan menyebabkan benda mudah retak bila diberi beban. Flow dinyatakan dalam satuan panjang. Nilai flow ditunjukkan oleh jarum arloji pembacaan flow pada alat Marshall. Untuk arloji pembacaan flow, nilai yang didapat sudah dalam satuan $\mathrm{mm}$, sehingga tidak perlu dikonversi lebih lanjut. 


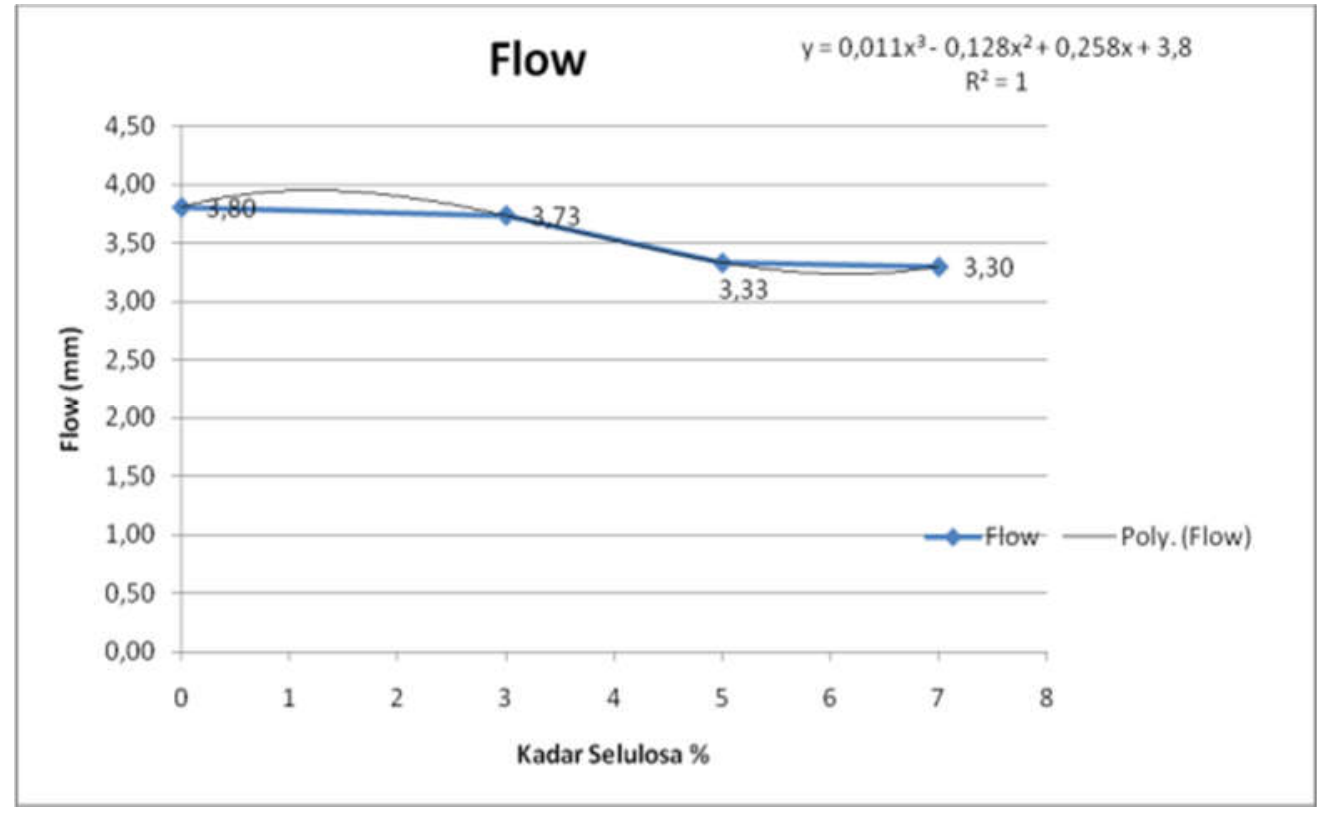

Gambar 5: Grafik Hubungan Void Filled With Asphalt dengan Kadar Serat Selulosa Sumber : Hasil Penelitian,2018

\section{Marshall Quotient}

Marshall Quotient adalah perbandingan antara nilai stabilitas dengan flow. Marshall Quotient merupakan indikator dalam menentukan nilai fleksibitas kelenturan terhadap keretakan. Kenaikan fleksibitas disebabkan oleh penambahan kadar aspal dan akan penurunan hingga batas optimum disebabkan oleh berubahnya fungsi aspal sebagai pengikat menjadi pelican.



Gambar 6 Grafik Hubungan Marshall Quotient dengan Kadar Serat Selulosa Sumber : Hasil Penelitian,2018

\section{KESIMPULAN}


Dari hasil penelitian yang dilakukan mengenai pengaruh penggunaan serat eceng gondok sebagai bahan pengganti serat selulosa pada campuran Laston Tipe XI SNI 03 - 1737 - 1989 yang telah dilakukan dapat ditarik kesimpulan sebagai berikut :

1. Pada proses pembuatan benda uji memiliki tahapan sebagai berikut ; pertama Pencarian eceng gondok sesuai kebutuhan dikali daerah deket, mencuci eceng gondok lalu menggilingnya, setelah digiling dikeringkan (dioven atau dijemur), timbang eceng gondok yang sudah menjadi serat sesuai kebutuhan, menimbang agregat sesuai presentase agregat campuran yang telah dihitungpada JMF ( Job Mix Formula ), Agregat dipanaskan dalam wajan dan diaduk hingga suhu mencapai $100^{\circ} \mathrm{C}$, Setelah mencapai suhu $100^{\circ} \mathrm{C}$ lalu ditambahkan aspal panas dan di campur sampai merata, setelah temperatur pemadatan tercapai, maka campuran tersebut dimasukkan ke dalam cetakan (mold) yang telah dipanasi $\left(100^{\circ} \mathrm{C}\right.$ hingga $\left.170^{\circ} \mathrm{C}\right)$ dan diolesi pelumas terlebih dahulu, pada bagian bawah cetakan dilapisi kertas yang telah dipotong sesuai dengan diameter cetakan (mold), Pemadatan standar dilakukan dengan alat Marshall dengan jumlah tumbukan 75 kali dibagian sisi atas kemudian dibalik dan sisi bagian bawah juga ditumbuk sebanyak 75 kali, Setelah proses pemadatan selesai benda uji didiamkan agar suhunya turun, setelah dingin benda uji dikeluarkan dengan ejektor dan diberi kode, Benda uji dibersihkan dari kotoran yang menempel dan diukur tinggi benda uji dan ditimbang beratnya di udara, Benda uji direndam dalam air selama $10-24$ jam supaya jenuh, Setelah jenuh benda uji ditimbang dalam air, Benda uji dikeluarkan dari bak perendam dan dikeringkan dengan kain pada permukaan agar kondisi kering permukaan jenuh (saturate surface dry, SSD) kemudian ditimbang.

2. Pada proses pengujian benda uji dilakukan dengan menggunakan metode Marshal Test dengan hasil sebagai berikut ; Pada kondisi aspal optimum Marshall Stability campuran semakin meningkat seiring bertambahnya prosentase kadar selulosa enceng gondok dalam campuran, pada kondisi aspal optimum persentase rongga dalam campuran (Void In The Mix) mengalami peningkatan seiring dengan bertambahnya persentase kadar selulosa enceng gondok dalam campuran, pada kondisi aspal optimum persentase rongga dalam campuran (Void In Mineral Aggregate) mengalami peningkatan seiring dengan bertambahnya persentase kadar selulosa enceng gondok dalam campuran, pada kondisi aspal optimum persentase rongga terisi aspal (Void Filled With Asphalt) mengalami penurunan seiring bertambahnya prosentase kadar selulosa dalam campuran, pada kondisi aspal optimum kelelahan plastis (flow) campuran semakin menurun seiring dengan bertambahnya persentase kadar selulosa enceng gondok dalam campuran, pada kondisi aspal optimum ternyata Marshall Quotient (MQ)mengalami peningkatan seiring bertambahnya persentase kadar selulosa dalam campuran.

\section{DAFTAR PUSTAKA}


[1] BSSNI, 1991.SKSNI 03-2417-1991.Metode Pengujian Keausan Agregat Dengan Mesin Abrasi Los Angeles

[2] BSSNI, 1991. SKSNI 03-2440-1991.MetodePengujianKehilanganBerat Minyak Dan Aspal

[3] BSSNI, 1997. SKSNI 03-4428-1997. Metode Pengujian Agregat Halus Atau Pasir Yang Mengandung Bahan Plastik Dengan Cara Setara Pasir

[4] BSSNI, 1998. SKSNI 03-4804-1998.Metode Pengujian Bobot Isi Dan Rongga Udara Dalam Agregat

[5] BSSNI, 2002. SKSNI 13-6717-2002.Tata Cara Penyiapan Benda Uji Dari Contoh Agregat

[6] BSSNI, 2008. SKSNI 1970-2008.Cara Uji Berat Jenis Dan Penyerapan Air Agregat Halus

[7] BSSNI, 2008. SKSNI 1969-2008.Cara Uji Berat Jenis Dan Penyerapan Air Agregat Kasar

[8] BSSNI, 2011.SKSNI 2433-2011.Cara uji titik nyala dan titik bakar aspal dengan alat cleveland open cup

[9] BSSNI, 2011. SKSNI 2439-2011. Cara Uji Penyelimutan Dan Pengelupasan Pada Campuran Agregat- Aspal

[10] BSSNI, 2011. SKSNI 2441-2011. Tentang Cara Uji Berat Jenis Aspal Keras

[11] BSSNI, 2011. SKSNI 2456-2011. Tentang Cara Uji Penetrasi Aspal

[12] BSSNI, SKSNI 03-6414-200. Spesifikasi Timbangan Yang Digunakan Pada Pengujian Bahan

[13] BSSNI, 2008. SKSNI 2417-2008.Cara Uji Keausan Agregat Dengan Mesin Abrasi Los Angeles

[14] BSSNI,2011. SKSNI 2434-2011. Tentang Cara UjiTitikLembekAspalDenganAlatCincin Dan Bola (Ring And Ball)

[15] Kumalawati, A., Tri, M.W., Mastaram, Y., 2013. Analisis Pengaruh Penggunaan Abu Batu Apung Sebagai Pengganti Filler Untuk Campuran Panas. Jurnal Teknik Sipil. Volume II. No 2., p.191-200.

[16] Laboratorium Teknik Sipil Universitas Islam Lamongan, 2016. Panduan Praktikum Pelaksanaan Perkerasan Jalan. Lamongan: Universitas Islam Lamongan SNI 031737-1989,Tata Cara Pelaksanaan LapisAspal Beton (Laston) Untuk Jalan Raya. Jakarta.

[17] Spesifikasi Umum, 2010 (Revisi 3). Lapis Resap Pengikat Dan Lapis Perekat. Jakarta 